4

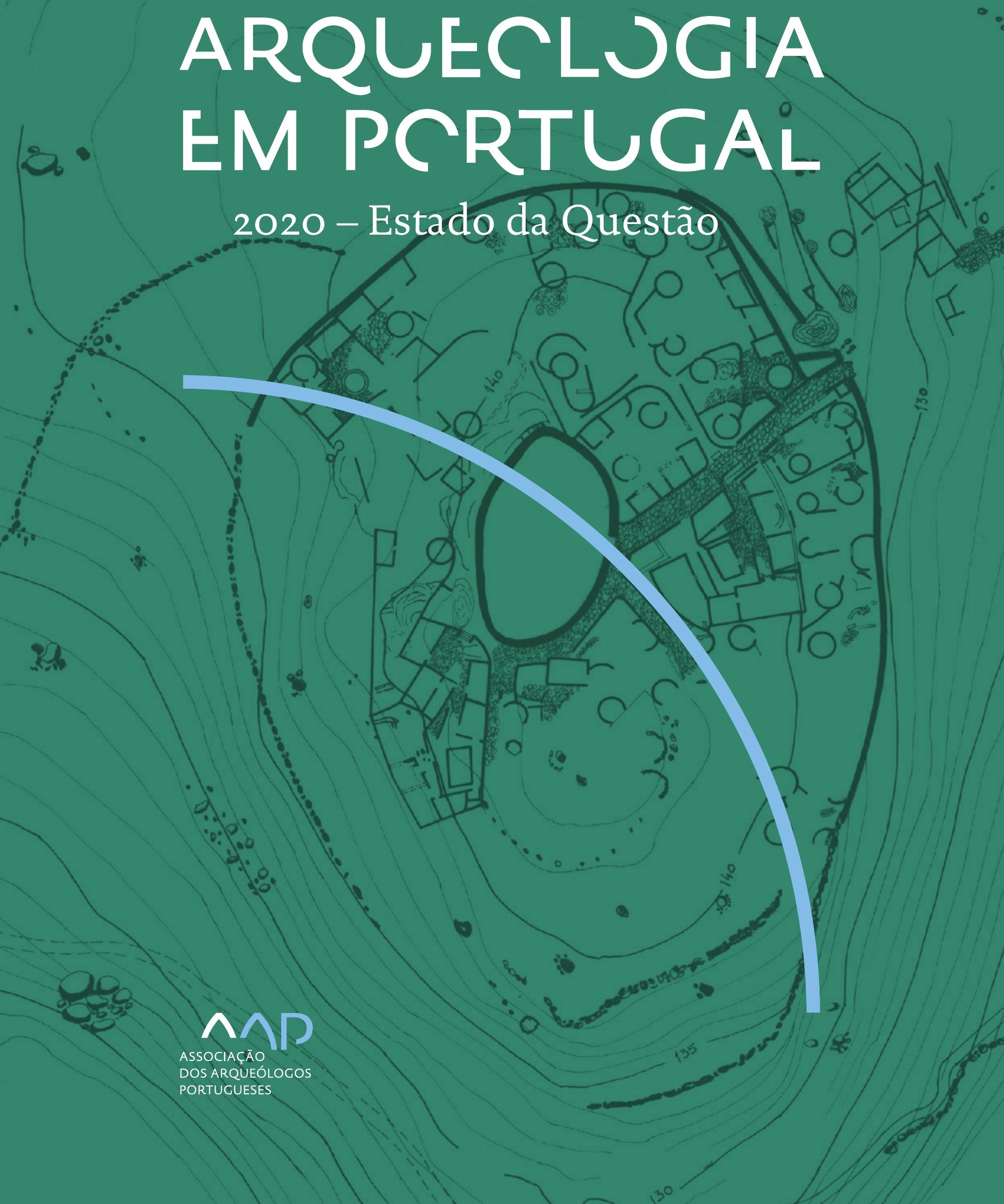


Coordenação editorial: José Morais Arnaud, César Neves e Andrea Martins Design gráfico: Flatland Design

AAP - ISBN: 978-972-9451-89-8

CITCEM - ISBN: 978-989-8970-25-1

Associação dos Arqueólogos Portugueses e CITCEM

Lisboa, 2020

O conteúdo dos artigos é da inteira responsabilidade dos autores. Sendo assim a Associação dos Arqueólogos Portugueses declina qualquer responsabilidade por eventuais equívocos ou questões de ordem ética e legal.

Desenho de capa:

Planta do castro de Monte Mozinho (Museu Municipal de Penafiel).

\section{$\hat{\wedge} \mathrm{P}$}

DOS ARQUEÓLOGOS PORTUGUESES

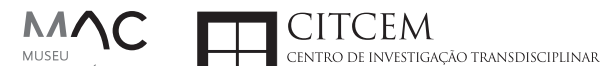
MUSEU
ARQUELLÓGICO
DO CARMO
U.PORTO

FLUP FACULDADE DE LETRAS
UNIVERSIDADE DO PORTO

Apoio

EC para a Ciência 


\section{Índice}

15 Prefácio

José Morais Arnaud

\section{Historiografia e Teoria}

17 Território, comunidade, memória e emoção: a contribuição da história da arqueologia (algumas primeiras e breves reflexões)

Ana Cristina Martins

25 Como descolonizar a arqueologia portuguesa?

Rui Gomes Coelho

41 Arqueologia e Modernidade: uma revisitação pessoal e breve de alguns aspetos da obra homónima de Julian Thomas de 2004

Vítor Oliveira Jorge

57 Dados para a História das Mulheres na Arqueologia portuguesa, dos finais do século XIX aos inícios do século XX: números, nomes e tabelas

Filipa Dimas / Mariana Diniz

73 Retractos da arqueologia portuguesa na imprensa: (in)visibilidades no feminino

Catarina Costeira / Elsa Luís

85 Arqueologia e Arqueólogos no Norte de Portugal Jacinta Bugalhão

101 Vieira Guimarães (1864-1939) e a arqueologia em Tomar: uma abordagem sobre o território e as gentes

João Amendoeira Peixoto / Ana Cristina Martins

115 Os memoráveis? A arqueologia algarvia na imprensa nacional e regional na presente centúria (2001-2019): características, visões do(s) passado(s) e a arqueologia

enquanto marca

Frederico Agosto / João Silva

129 A Evolução da Arqueologia Urbana e a Valorização Patrimonial no Barlavento Algarvio: Os casos de Portimão e Silves

Artur Mateus / Diogo Varandas / Rafael Boavida

\section{Gestão, Valorização e Salvaguarda do Património}

145 O Caderno Reivindicativo e as condições de trabalho em Arqueologia Miguel Rocha / Liliana Matias Carvalho / Regis Barbosa / Mauro Correia / Sara Simões / Jacinta Bugalhão / Sara Brito / Liliana Veríssimo Carvalho / Richard Peace / Pedro Peça / Cézer Santos

155 Os Estudos de Impacte Patrimonial como elemento para uma estratégia sustentável de minimização de impactes no âmbito de reconversões agrícolas Tiago do Pereiro

165 Salvaguarda de Património arqueológico em operações florestais: gestão e sensibilização Filipa Bragança / Gertrudes Zambujo / Sandra Lourenço / Belém Paiva / Carlos Banha / Frederico Tatá Regala / Helena Moura / Jacinta Bugalhão / João Marques / José Correia / Pedro Faria / Samuel Melro

179 Os valores do Património: uma investigação sobre os Sítios Pré-históricos de Arte Rupestre do Vale do Rio Côa e de Siega Verde José Paulo Francisco 
189 Conjugando recursos arqueológicos e naturais para potenciar as visitas ao Geoparque Litoral de Viana do Castelo (Noroeste de Portugal)

Hugo A. Sampaio / Ana M.S. Bettencourt / Susana Marinho / Ricardo Carvalhido

203 Áreas de Potencial Arqueológico na Região do Médio Tejo: Modelo Espacial Preditivo Rita Ferreira Anastácio / Ana Filipa Martins / Luiz Oosterbeek

223 Património Arqueológico e Gestão Territorial: O contributo da Arqueologia para a revisão do PDM de Avis

Ana Cristina Ribeiro

237 A coleção arqueológica do extinto Museu Municipal do Porto - Origens, Percursos e Estudos

Sónia Couto

251 Valpaços - uma nova carta arqueológica

Pedro Pereira / Maria de Fátima Casares Machado

263 Arqueologia na Cidade de Peniche

Adriano Constantino / Luís Rendeiro

273 Arqueologia Urbana: a cidade de Lagos como caso de Estudo Cátia Neto

285 Estratégias de promoção do património cultural subaquático nos Açores. O caso da ilha do Faial

José Luís Neto / José Bettencourt / Luís Borges / Pedro Parreira

297 Carta Arqueológica da Cidade Velha: Uma primeira abordagem

Jaylson Monteiro / Nireide Tavares / Sara da Veiga / Claudino Ramos / Edson Brito /

Carlos Carvalho / Francisco Moreira / Adalberto Tavares

311 Antropologia Virtual: novas metodologias para a análise morfológica e funcional Ricardo Miguel Godinho / Célia Gonçalves

\section{Didáctica da Arqueologia}

327 Como os projetos de Arqueologia podem contribuir para uma comunidade culturalmente mais consciente Alexandra Figueiredo / Claúdio Monteiro / Adolfo Silveira / Ricardo Lopes

337 Educação Patrimonial - Um cidadão esclarecido é um cidadão ativo! Ana Paula Almeida

351 A aproximação da Arqueologia à sala de aula: um caso de estudo no $3^{\circ}$ ciclo do Ensino Básico Luís Serrão Gil

363 Arqueologia 3.o - Pensar e comunicar a Arqueologia para um futuro sustentável Mónica Rolo

377 “Conversa de Arqueólogos" - Divulgar a Arqueologia em tempos de Pandemia Diogo Teixeira Dias

389 Escola Profissional de Arqueologia: desafios e oportunidades Susana Nunes / Dulcineia Pinto / Júlia Silva / Ana Mascarenhas

399 Os Museus de Arqueologia e os Jovens: a oferta educativa para o público adolescente Beatriz Correia Barata / Leonor Medeiros

411 O museu universitário como mediador entre a ciência e a sociedade: o exemplo da secção de arqueologia no Museu de História Natural e da Ciência da Universidade do Porto (MHNC-UP)

Rita Gaspar 
421 Museu de Lanifícios: Real Fábrica de Panos. Atividades no âmbito da Arqueologia Beatriz Correia Barata / Rita Salvado

427 Arqueologia Pública e o caso da localidade da Mata (Torres Novas) Cláudia Manso / Ana Rita Ferreira / Cristiana Ferreira / Vanessa Cardoso Antunes

431 Do sítio arqueológico ao museu: um percurso (também) didático Lídia Fernandes

447 Estão todos convidados para a Festa! E para dançar também... O projecto do Serviço Educativo do Museu Arqueológico do Carmo na $5^{\underline{a}}$ Edição da Festa da Arqueologia Rita Pires dos Santos

459 O “Clã de Carenque”, um projeto didático de arqueologia Eduardo Gonzalez Rocha

469 Mediação cultural: peixe que puxa carroça nas Ruínas Romanas de Troia Inês Vaz Pinto / Ana Patrícia Magalhães / Patrícia Brum / Filipa Santos

481 Didática Arqueológica, experiências do Projeto Mértola Vila Museu Maria de Fátima Palma / Clara Rodrigues / Susana Gómez / Lígia Rafael

\section{Arte Rupestre}

497 Os inventários de arte rupestre em Portugal Mila Simões de Abreu

513 O projeto FIRST-ART - conservação, documentação e gestão das primeiras manifestações de arte rupestre no Sudoeste da Península Ibérica: as grutas do Escoural e Maltravieso Sara Garcês / Hipólito Collado / José Julio García Arranz / Luiz Oosterbeek / António Carlos Silva / Pierluigi Rosina / Hugo Gomes / Anabela Borralheiro Pereira / George Nash / Esmeralda Gomes / Nelson Almeida / Carlos Carpetudo

523 Trabalhos de documentação de arte paleolítica realizados no âmbito do projeto PalæoCôa André Tomás Santos / António Fernando Barbosa / Luís Luís / Marcelo Silvestre / Thierry Aubry

537 Imagens fantasmagóricas, silhuetas elusivas: as figuras humanas na arte do Paleolítico Superior da região do Côa Mário Reis

$55^{1}$ Os motivos zoomórficos representados nas placas de tear de Vila Nova de São Pedro (Azambuja, Portugal) Andrea Martins / César Neves / José M. Arnaud / Mariana Diniz

571 Arte Rupestre do Monte de Góios (Lanhelas, Caminha). Síntese dos resultados dos trabalhos efectuados em 2007-2009 Mário Varela Gomes

599 Gravuras rupestres de barquiformes no Monte de S. Romão, Guimarães, Noroeste de Portugal Daniela Cardoso

613 Círculos segmentados gravados na Bacia do Rio Lima (Noroeste de Portugal): contributos para o seu estudo Diogo Marinho / Ana M.S. Bettencourt / Hugo Aluai Sampaio

631 Equídeos gravados no curso inferior do Rio Mouro, Monção (NW Portugal). Análise preliminar Coutinho, L.M. / Bettencourt, A.M.S / Sampaio, Hugo A.S

645 Paletas na Arte Rupestre do Noroeste de Portugal. Inventário preliminar Bruna Sousa Afonso / Ana M. S. Bettencourt / Hugo A. Sampaio 


\section{Pré-História}

661 O projeto Miño/Minho: balanço de quatro anos de trabalhos arqueológicos Sérgio Monteiro-Rodrigues / João Pedro Cunha-Ribeiro / Eduardo Méndez-Quintas / Carlos Ferreira / Pedro Xavier / José Meireles / Alberto Gomes / Manuel Santonja / Alfredo Pérez-González

677 A ocupação paleolítica da margem esquerda do Baixo Minho: a indústria lítica do sítio de Pedreiras 2 (Monção, Portugal) e a sua integração no contexto regional Carlos Ferreira / João Pedro Cunha-Ribeiro / Sérgio Monteiro-Rodrigues / Eduardo Méndez-Quintas / Pedro Xavier / José Meireles / Alberto Gomes / Manuel Santonja / Alfredo Pérez-González

693 O sítio acheulense do Plistocénico médio da Gruta da Aroeira Joan Daura / Montserrat Sanz / Filipa Rodrigues / Pedro Souto / João Zilhão

703 As sociedades neandertais no Barlavento algarvio: modelos preditivos com recurso aos SIG

Daniela Maio

715 A utilização de quartzo durante o Paleolítico Superior no território dos vales dos rios Vouga e Côa

Cristina Gameiro / Thierry Aubry / Bárbara Costa / Sérgio Gomes / Luís Luís / Carmen Manzano / André Tomás Santos

733 Uma perspetiva diacrónica da ocupação do concheiro do Cabeço da Amoreira (Muge, Portugal) a partir da tecnologia lítica Joana Belmiro / João Cascalheira / Célia Gonçalves

745 Novos dados sobre a Pré-história Antiga no concelho de Palmela. A intervenção arqueológica no sítio do Poceirão I

Michelle Teixeira Santos

757 Problemas em torno de Datas Absolutas Pré-Históricas no Norte do Alentejo Jorge de Oliveira

771 Povoamento pré-histórico nas áreas montanhosas do NO de Portugal: o Abrigo 1 de Vale de Cerdeira Pedro Xavier / José Meireles / Carlos Alves

783 Apreciação do povoamento do Neolítico Inicial na Baixa Bacia do Douro. A Lavra I (Serra da Aboboreira) como caso de estudo Maria de Jesus Sanches

797 O Processo de Neolitização na Plataforma do Mondego: os dados do Sector C do Outeiro dos Castelos de Beijós (Carregal do Sal)

João Carlos de Senna-Martinez / José Manuel Quintã Ventura / Andreia Carvalho / Cíntia Maurício

823 Novos trabalhos na Lapa da Bugalheira (Almonda, Torres Novas) Filipa Rodrigues / Pedro Souto / Artur Ferreira / Alexandre Varanda / Luís Gomes / Helena Gomes / João Zilhão

837 A pedra polida e afeiçoada do sítio do Neolítico médio da Moita do Ourives (Benavente, Portugal)

César Neves

857 Casal do Outeiro (Encarnação, Mafra): novos contributos para o conhecimento do povoamento do Neolítico final na Península de Lisboa.

Cátia Delicado / Carlos Maneira e Costa / Marta Miranda / Ana Catarina Sousa

873 Stresse infantil, morbilidade e mortalidade no sítio arqueológico do Neolítico Final/ Calcolítico ( $4^{\circ}$ e $3^{\circ}$ milénio a.C.) do Monte do Carrascal 2 (Ferreira do Alentejo, Beja) Liliana Matias de Carvalho / Sofia N. Wasterlain 
885 Come together: O Conjunto Megalítico das Motas (Monção, Viana do Castelo) e as expressões Campaniformes do Alto Minho Ana Catarina Basílio / Rui Ramos

899 Trabalhos arqueológicos no sítio Calcolítico da Pedreira do Poio Carla Magalhães / João Muralha / Mário Reis / António Batarda Fernandes

913 O sítio arqueológico de Castanheiro do Vento. Da arquitectura do sítio à arquitectura de um território João Muralha Cardoso

925 Estudo zooarqueológico das faunas do Calcolítico final de Vila Nova de São Pedro (Azambuja, Portugal): Campanhas de 2017 e 2018 Cleia Detry / Ana Catarina Francisco / Mariana Diniz / Andrea Martins / César Neves / José Morais Arnaud

943 As faunas depositadas no Museu Arqueológico do Carmo provenientes de Vila Nova de São Pedro (Azambuja): as campanhas de 1937 a 1967 Ana Catarina Francisco / Cleia Detry / César Neves / Andrea Martins / Mariana Diniz / José Morais Arnaud

959 Análise funcional de material lítico em sílex do castro de Vila Nova de S. Pedro (Azambuja, Portugal): uma primeira abordagem Rafael Lima

971 O recinto da Folha do Ouro 1 (Serpa) no contexto dos recintos de fossos calcolíticos alentejanos

António Carlos Valera / Tiago do Pereiro / Pedro Valério / António M. Monge Soares

\section{Proto-História}

987 Produção de sal marinho na Idade do Bronze do noroeste Português. Alguns dados para uma reflexão

Ana M. S. Bettencourt / Sara Luz / Nuno Oliveira / Pedro P. Simões / Maria Isabel C. Alves / Emílio Abad-Vidal

1001 A estátua-menir do Pedrão ou de São Bartolomeu do Mar (Esposende, noroeste de Portugal) no contexto arqueológico da fachada costeira de entre os rios Neiva e Cávado Ana M. S. Bettencourt / Manuel Santos-Estévez / Pedro Pimenta Simões / Luís Gonçalves

1015 O Castro do Muro (Vandoma/Baltar, Paredes) - notas para uma biografia de ocupação da Idade do Bronze à Idade Média

Maria Antónia D. Silva / Ana M. S. Bettencourt / António Manuel S. P. Silva / Natália Félix

1031 Do Bronze Final à Idade Média - continuidades e hiatos na ocupação de Povoados em Oliveira de Azeméis João Tiago Tavares / Adriaan de Man

1041 As faunas do final da Idade do Bronze no Sul de Portugal: leituras desde o Outeiro do Circo (Beja)

Nelson J. Almeida / Íris Dias / Cleia Detry / Eduardo Porfírio / Miguel Serra

1055 A Espada do Monte das Oliveiras (Serpa) - uma arma do Bronze Pleno do Sudoeste Rui M. G. Monge Soares / Pedro Valério / Mariana Nabais / António M. Monge Soares

1065 São Julião da Branca (Albergaria-a-Velha) - Investigação e valorização de um povoado do Bronze Final

António Manuel S. P. Silva / Paulo A. P. Lemos / Sara Almeida e Silva / Edite Martins de Sá

1083 Do castro de S. João ao Mosteiro de Santa Clara: notícia de uma intervenção arqueológica, em Vila do Conde Rui Pinheiro 
1095 O castro de Ovil (Espinho), um quarto de século de investigação - resultados e questões em aberto

Jorge Fernando Salvador / António Manuel S. P. Silva

1111 O Castro de Salreu (Estarreja), um povoado proto-histórico no litoral do Entre Douro e Vouga

Sara Almeida e Silva / António Manuel S. P. Silva / Paulo A. P. Lemos / Edite Martins de Sá

1127 Castro de Nossa Senhora das Necessidades (Sernancelhe): uma primeira análise artefactual Telma Susana O. Ribeiro

${ }_{1141}$ A cividade de Bagunte. O estado atual da investigação Pedro Brochado de Almeida

1153 Zoomorfos na cerâmica da Idade do Ferro no NW Peninsular: inventário, cronologias e significado Nuno Oliveira / Cristina Seoane

1163 Vasos gregos em Portugal: diferentes maneiras de contar a história do intercâmbio cultural na Idade do Ferro

Daniela Ferreira

1175 Os exotica da necrópole da Idade do Ferro do Olival do Senhor dos Mártires (Alcácer do Sal) no seu contexto regional

Francisco B. Gomes

\section{Antiguidade Clássica e Tardia}

1191 O uso de madeira como combustível no sítio da Quinta de Crestelos (Baixo Sabor): da Idade do Ferro à Romanização Filipe Vaz / João Tereso / Sérgio Simões Pereira / José Sastre / Javier Larrazabal Galarza / Susana Cosme / José António Pereira / Israel Espi

1207 Cultivos de Época Romana no Baixo Sabor: continuidade em tempos de mudança? João Pedro Tereso / Sérgio Simões Pereira / Filipe Santos / Luís Seabra / Filipe Vaz

1221 A casa romana na Hispânia: aplicação dos modelos itálicos nas províncias ibéricas Fernanda Magalhães / Diego Machado / Manuela Martins

1235 As pinturas murais romanas da Rua General Sousa Machado, n. ${ }^{5}$ 1, Chaves José Carvalho

1243 Trás do Castelo (Vale de Mir, Pegarinhos, Alijó) - Uma exploração agrícola romana do Douro

Tony Silvino / Pedro Pereira

1255 A sequência de ocupação no quadrante sudeste de Bracara Augusta: as transformações de uma unidade doméstica Lara Fernandes / Manuela Martins

1263 Os Mosaicos com decoração geométrica e geométrico-vegetalista dos sítios arqueológicos da área do Conuentus Bracaraugustanus. Novas abordagens quanto à conservação, restauro, decoração e datação Maria de Fátima Abraços / Licínia Wrench

1277 “Casa Romana” do Castro de São Domingos (Cristelos, Lousada): Escavação, Estudo e Musealização Paulo André de P. Lemos

1291 A arqueobotânica no Castro de Guifões (Matosinhos, Noroeste de Portugal): O primeiro estudo carpológico

Luís Seabra / Andreia Arezes / Catarina Magalhães / José Varela / João Pedro Tereso 
1305 Um Horreum Augustano na Foz do Douro (Monte do Castelo de Gaia, Vila Nova de Gaia) Rui Ramos

1311 Ponderais romanos na Lusitânia: padrões, formas, materiais e contextos de utilização Diego Barrios Rodríguez

1323 Um almofariz centro-itálico na foz do Mondego

Marco Penajoia

1335 Estruturas romanas de Carnide - Lisboa Luísa Batalha / Mário Monteiro / Guilherme Cardoso

1347 O contexto funerário do sector da "necrópole NO" da Rua das Portas de S. Antão (Lisboa): o espaço, os artefactos, os indivíduos e a sua interconectividade na interpretação do passado Sílvia Loja, José Carlos Quaresma, Nelson Cabaço, Marina Lourenço, Sílvia Casimiro, Rodrigo Banha da Silva, Francisca Alves-Cardoso

${ }_{1361}$ Povoamento em época Romana na Amadora - resultados de um projeto pluridisciplinar Gisela Encarnação / Vanessa Dias

1371 A Arquitectura Residencial em Mirobriga (Santiago do Cacém): contributo a partir de um estudo de caso Filipe Sousa / Catarina Felício

${ }_{1385}$ O fim do ciclo. Saneamento e gestão de resíduos nos edifícios termais de Mirobriga (Santiago do Cacém)

Catarina Felício / Filipe Sousa

1399 Balsa, Topografia e Urbanismo de uma Cidade Portuária Vítor Silva Dias / João Pedro Bernardes / Celso Candeias / Cristina Tété Garcia

1413 No Largo das Mouras Velhas em Faro (2017): novas evidências da necrópole norte de Ossonoba e da sua ocupação medieval Ricardo Costeira da Silva / Paulo Botelho / Fernando Santos / Liliana Nunes

1429 Instrumentos de pesca recuperados numa fábrica de salga em Ossonoba (Faro) Inês Rasteiro / Ricardo Costeira da Silva / Paulo Botelho

1439 A Necrópole Romana do Eirô, Duas Igrejas (Penafiel): intervenção arqueológica de 2016 Laura Sousa / Teresa Soeiro

1457 Ritual, descarte ou afetividade? A presença de Canis lupus familiaris na Necrópole Noroeste de Olisipo (Lisboa)

Beatriz Calapez Santos / Sofia Simões Pereira / Rodrigo Banha da Silva / Sílvia Casimiro / Cleia Detry / Francisca Alves Cardoso

1467 Dinâmicas económicas em Bracara na Antiguidade Tardia Diego Machado / Manuela Martins / Fernanda Magalhães / Natália Botica

1479 Cerâmicas e Vidros da Antiguidade Tardia do Edifício sob a Igreja do Bom Jesus (Vila Nova de Gaia) Joaquim Filipe Ramos

1493 Novos contributos para a topografia histórica de Mértola no período romano e na Antiguidade Tardia Virgílio Lopes

\section{8. Época Medieval}

1511 Cerâmicas islâmicas no Garb setentrional "português": algumas evidências e incógnitas Constança dos Santos / Helena Catarino / Susana Gómez / Maria José Gonçalves / Isabel Inácio / Gonçalo Lopes / Jacinta Bugalhão / Sandra Cavaco / Jaquelina Covaneiro / Isabel Cristina Fernandes / Ana Sofia Gomes 
1525 Contributo para o conhecimento da cosmética islâmica, em Silves, durante a Idade Média Rosa Varela Gomes

1537 Yábura e o seu território - uma análise histórico-arqueológica de Évora entre os séculos VIII-XII José Rui Santos

1547 A encosta sul do Castelo de Palmela - resultados preliminares da escavação arqueológica Luís Filipe Pereira / Michelle Teixeira Santos

1559 A igreja de São Lourenço (Mouraria, Lisboa): um conjunto de silos e de cerâmica medieval islâmica

Andreia Filipa Moreira Rodrigues

1571 O registo material de movimentações populacionais no Médio Tejo, durante os séculos XII-XIII. Dois casos de "sunken featured buildings", nos concelhos de Cartaxo e Torres Novas Marco Liberato / Helena Santos / Nuno Santos

1585 O nordeste transmontano nos alvores da Idade média. Notas para reflexão Ana Maria da Costa Oliveira

1601 Sepulturas escavadas na rocha do Norte de Portugal e do Vale do Douro: primeiros resultados do Projecto SER-NPVD

Mário Jorge Barroca / César Guedes / Andreia Arezes / Ana Maria Oliveira

1619 "Portucalem Castrum Novum" entre o Mediterrâneo e o Atlântico: o estudo dos materiais cerâmicos alto-medievais do arqueossítio da rua de D. Hugo, nํ. 5 (Porto) João Luís Veloso

1627 A Alta Idade Média na fronteira de Lafões: notas preliminares sobre a Arqueologia no Concelho de Vouzela

Manuel Luís Real / Catarina Tente

1641 Um conjunto cerâmico medieval fora de portas: um breve testemunho aveirense Susana Temudo

${ }_{1651}$ Os Lóios do Porto: uma perspetiva integrada no panorama funerário da Baixa Idade Média à Época Moderna em meios urbanos em Portugal

Ana Lema Seabra

1659 O Caminho Português Interior de Santiago como eixo viário na Idade Média Pedro Azevedo

1665 Morfologia Urbana: Um exercício em torno do Castelo de Ourém André Donas-Botto / Jaqueline Pereira

1677 Intervenção arqueológica na Rua Marquês de Pombal/Largo do Espírito Santo (Bucelas, Loures)

Florbela Estêvão / Nathalie Antunes-Ferreira / Dário Ramos Neves / Inês Lisboa

1691 O Cemitério Medieval do Poço do Borratém e a espacialidade funerária na cidade de Lisboa Inês Belém / Vanessa Filipe / Vasco Noronha Vieira / Sónia Ferro / Rodrigo Banha da Silva

1705 Um Espaço Funerário Conventual do séc. XV em Lisboa: o caso do Convento de São Domingos da Cidade Sérgio Pedroso / Sílvia Casimiro / Rodrigo Banha da Silva / Francisca Alves Cardoso

\section{9. Época Moderna e Contemporânea}

1721 Arqueologia Moderna em Portugal: algumas reflexões críticas em torno da quantificação de conjuntos cerâmicos e suas inferências históricas e antropológicas Rodrigo Banha da Silva / André Bargão / Sara da Cruz Ferreira

1733 Faianças de dois contextos entre os finais do século XVI e XVIII do Palácio dos Condes de Penafiel, Lisboa

Martim Lopes / Tomás Mesquita 
1747 Um perfil de consumo do século XVIII na foz do Tejo: O caso do Mercado da Ribeira, Lisboa Sara da Cruz Ferreira / Rodrigo Banha da Silva / André Bargão

1761 Os Cachimbos dos Séculos XVII e XVIII do Palácio Mesquitela e Convento dos Inglesinhos (Lisboa)

Inês Simão / Marina Pinto / João Pimenta / Sara da Cruz Ferreira / André Bargão / Rodrigo Banha da Silva

1775 "Tomar os fumos da erua que chamão em Portugal erua sancta». Estudo de Cachimbos provenientes da Rua do Terreiro do Trigo, Lisboa

Miguel Martins de Sousa / José Pedro Henriques / Vanessa Galiza Filipe

1787 Cachimbos de Barro Caulínitico da Sé da Cidade Velha (República de Cabo Verde)

Rodrigo Banha da Silva / João Pimenta / Clementino Amaro

1801 Algumas considerações sobre espólio não cerâmico recuperado no Largo de Jesus (Lisboa) Carlos Boavida

1815 Adereços de vidro, dos séculos XVI-XVIII, procedentes do antigo Convento de Santana de Lisboa (anéis, braceletes e contas)

Joana Gonçalves / Rosa Varela Gomes / Mário Varela Gomes

1837 Da ostentação, luxo e poder à simplicidade do uso quotidiano: arqueologia e simbologia de joias e adornos da Idade Moderna Portuguesa Jéssica Iglésias

1849 Os amuletos em Portugal - dos objetos às superstições: o coral vermelho Alexandra Vieira

1865 Cerâmicas de Vila Franca de Xira nos séculos XV e XVI Eva Pires

1879 «Não passa por teu o que me pertence». Marcas de individualização associadas a faianças do Convento de Nossa Senhora de Aracoeli, Alcácer do Sal Catarina Parreira / Íris Fragoso / Miguel Martins de Sousa

1891 Cerâmica de Leiria: alguns focos de produção

Jaqueline Pereira / André Donas-Botto

1901 Os Fornos na Rua da Biquinha, em Óbidos Hugo Silva / Filipe Oliveira

1909 A casa de Pêro Fernandes, contador dos contos de D. Manuel I: o sítio arqueológico da Silha do Alferes, Seixal (século XVI) Mariana Nunes Ferreira

1921 O Alto da Vigia (Sintra) e a vigilância e defesa da costa Alexandre Gonçalves / Sandra Santos

1937 O contexto da torre sineira da Igreja de Santa Maria de Loures Paulo Calaveira / Martim Lopes

1949 A Necrópole do Hospital Militar do Castelo de São Jorge e as práticas funerárias na Lisboa de Época Moderna Susana Henriques / Liliana Matias de Carvalho / Ana Amarante / Sofia N. Wasterlain

1963 SAND - Sarilhos Grandes Entre dois Mundos: o adro da Igreja e a Paleobiologia dos ossos humanos recuperados

Paula Alves Pereira / Roger Lee Jesus / Bruno M. Magalhães

1975 Expansão urbana da vila de Cascais no século XVII e XVIII: a intervenção arqueológica na Rua da Vitória no 15 a 17

Tiago Pereira / Vanessa Filipe

1987 Novos dados para o conhecimento do Urbanismo de Faro em época Moderna Ana Rosa 
1995 Um exemplo de Arqueologia Urbana em Alcoutim: o Antigo Edifício dos CTT Marco Fernandes / Marta Dias / Alexandra Gradim / Virgílio Lopes / Susana Gómez Martínez

2007 Palácio dos Ferrazes (Rua das Flores/Rua da Vitória, Porto): a cocheira de Domingos Oliveira Maia

Francisco Raimundo

2021 As muitas vidas de um edifício urbano: História, Arqueologia e Antropologia no antigo Recreatório Paroquial de Penafiel Helena Bernardo / Jorge Sampaio / Marta Borges

2035 O convento de Nossa Senhora da Esperança de Ponta Delgada: o contributo da arqueologia para o conhecimento de um monumento identitário João Gonçalves Araújo / N’Zinga Oliveira

2047 Arqueologia na ilha do Corvo... em busca da capela de Nossa Senhora do Rosário Tânia Manuel Casimiro / José Luís Neto / Luís Borges / Pedro Parreira

2059 Perdidos à vista da Costa. Trabalhos arqueológicos subaquáticos na Barra do Tejo Jorge Freire / José Bettencourt / Augusto Salgado

2071 Arqueologia marítima em Cabo Verde: enquadramento e primeiros resultados do projecto CONCHA

José Bettencourt / Adilson Dias / Carlos Lima / Christelle Chouzenoux / Cristóvão Fonseca / Dúnia Pereira / Gonçalo Lopes / Inês Coelho / Jaylson Monteiro / José Lima / Maria Eugénia Alves / Patrícia Carvalho / Tiago Silva

2085 Trabalhos arqueológicos na Cidade Velha (Ribeira Grande de Santiago, Cabo Verde): reflexões sobre um projecto de investigação e divulgação patrimonial André Teixeira / Jaylson Monteiro / Mariana Mateus / Nireide Tavares / Cristovão Fonseca / Gonçalo C. Lopes / Joana Bento Torres / Dúnia Pereira / André Bargão / Aurélie Mayer / Bruno Zélie / Carlos Lima / Christelle Chouzenoux / Inês Henriques / Inês Pinto Coelho / José Lima / Patrícia Carvalho / Tiago Silva

2103 A antiga fortificação de Quelba / Khor Kalba (E.A.U.). Resultados de quatro campanhas de escavações, problemáticas e perspectivas futuras Rui Carita / Rosa Varela Gomes / Mário Varela Gomes / Kamyar Kamyad

2123 Colónias para homens novos: arqueologia da colonização agrária fascista no noroeste ibérico Xurxo Ayán Vila / José Mạ . Señorán Martín 


\title{
MEDIAÇÃO CULTURAL: PEIXE QUE PUXA CARROÇA NAS RUÍNAS ROMANAS DE TROIA
}

Inês Vaz Pintoํ, Ana Patrícia Magalhães², Patrícia Brum³ ${ }^{3}$ Filipa Santos 4

\begin{abstract}
RESUMO
O projeto de valorização do centro de produção de salgas de peixe romano de Troia, iniciado em 2006, tem uma forte componente de mediação cultural em resposta, à partida, ao interesse do público. Prosseguiu como um desenvolvimento natural da investigação e da valorização do sítio arqueológico, aberto ao público em 2011, e tornou-se uma proposta de atividades culturais e um forte investimento na educação patrimonial.

Esta mediação cultural tem tido múltiplas "carroças", salientando-se a visita ao sítio, em particular a visita guiada, mas também os programas escolares e as animações temáticas para crianças e adultos, através de pequenos e grandes eventos. O seu objetivo último é o conhecimento e reconhecimento do monumento como herança cultural que importa respeitar e preservar.

Palavras-chave: Mediação cultural, Comunicação de ciência, Educação Patrimonial, Ruínas Romanas de Tróia, Troia.
\end{abstract}

\begin{abstract}
The enhancement project of the Roman fish-salting production centre of Troia began in 2006 with a strong component of cultural mediation answering the demand of the public. This mediation continued as a natural development of the investigation and valorization of the site, opened to the public in 2011, and became a proposal of cultural activities and a strong investment in heritage education.

Several "carts" have been pulling this cultural mediation, such as the visit of the site, and specially the guided tour, but also school programs and thematic animations for children and adults through small and large events. The main goal is the knowledge and the recognition of the monument as cultural inheritance to be respected and preserved.
\end{abstract}

Keywords: Cultural mediation, Science communication, Heritage education, Roman Ruins of Troia, Troia.

\section{OS CAMINHOS QUE SE ABREM: INTRODUÇÃO}

Com o projecto de valorização das Ruínas Romanas de Troia (Pinto, Magalhães e Brum, 2014) abriram-se ao público formalmente, pela primeira vez, as portas deste sítio arqueológico com séculos de investigação. A necessidade já vinha sendo sentida e, mesmo sem percursos instalados, muitas foram as visitas que se foram realizando ao longo dos anos.
Recentemente, antes da abertura, várias equipas, como as do Museu de Arqueologia e Etnografia do Distrito de Setúbal (MAEDS) e do Instituto do Património Arquitectónico e Arqueológico (IPPAR) já vinham proporcionando visitas ao sítio de forma não regular, respondendo à já existente procura. Desde o início do referido projecto de valorização, foi necessário integrar e respeitar o interesse dos visitantes pelo sítio arqueológico e pelos trabalhos em curso. A partir de Agosto de 2008, criou-se um

\footnotetext{
1. Troia Resort; CEAACP - Univ. Coimbra; ivpinto@troiaresort.pt

2. CECH - Univ. Coimbra |FCT - Fundação para a Ciência e a Tecnologia, I.P.; a.patriciamagalhaes@gmail.com

3. Troia Resort; CFE-HTC; psbrum@troiaresort.pt

4. filipa.ar.santos@hotmail.com
} 
calendário de visitas, que concentrou os visitantes, para que os trabalhos a decorrer não fossem interrompidos. Em 2010, com a instalação de um percurso de visita numa parte das Ruínas Romanas de Tróia e respectivo horário de funcionamento, as visitas passaram a ser cobradas aos visitantes. De notar que o cobrar de um valor de visita não implicou uma quebra nos números de visitantes, antes pelo contrário, verificou-se uma valorização da mesma, e foi possível manter a gratuitidade para crianças até aos 14 anos, escolas, IPSS e outras instituições afins, que, desta forma, não perderam o acesso e usufruto do Monumento Nacional.

Foram instalados sete painéis explicativos e sinalética de orientação que tornaram possível visitar uma parte representativa do sítio arqueológico sem guia, a partir do dia 1 de Março de 2011. A inauguração oficial do novo percurso de visita decorreu no dia 1 de Junho desse mesmo ano.

O número de visitantes foi gradualmente aumentando, como era expectável (Figura 1), ainda que com uma quebra em 2015, relacionada com a diminuição de participantes no Mercado Romano, adiante referida, e novo aumento em 2018, quando, já sem este grande evento, se alarga o horário de visita de Março a Outubro, de quarta a domingo.

As visitas guiadas, calendarizadas a partir de 2008, foram fonte de experimentação e de recolha de conhecimento para o desenvolvimento dos próprios percursos. Desde 2008 que se realizavam visitas guiadas regulares, mas com a implantação dos percursos em 2010, estas foram cada vez mais frequentes e divulgadas.

Contudo, a experiência de mediação cultural neste sítio arqueológico, que pretendemos apresentar neste artigo, não se limitou às visitas guiadas/ orientadas.

\section{O PUXAR DA CARROÇA: A EXPERIÊNCIA DOS ÚLTIMOS DEZ ANOS DE MEDIAÇÃO CULTURAL EM TROIA}

Convidando-se e permitindo-se, a partir de então e cada vez mais, o usufruto deste espaço, as experiências foram muito diversas. Apresentamos, genericamente, algumas das que foram produzidas pela equipa de arqueologia do Troia Resort.

Desde 2009, os diversos programas de Passagem de Ano, Carnaval, Páscoa e Verão do Troia Resort passaram a integrar actividades relacionadas com o sítio arqueológico especiais para crianças e promoveram-se animações para adultos, como, por exemplo, passeios pedestres ou sessões de alongamentos, procurando atrair ao sítio quem estava hospedado sazonalmente nas proximidades (Figura 2).

Por outro lado, contrariando a sazonalidade deste território, um conjunto de três encontros deram a conhecer a região envolvente do maior centro de produção de salga de peixe do Império Romano, intimamente ligada a esta indústria com a já mais recente tradição conserveira. O objectivo desta acção era dar a conhecer a riqueza dos recursos naturais e patrimoniais da região, mas esta possibilitou igualmente uma maior integração da equipa recém-chegada e abriu as portas deste "tesouro científico" dos arqueólogos (Leite de Vasconcelos, 1897: 265) a um público mais vasto. Três edições tiveram lugar: Memórias de Tróia, em 2012; Memórias da Arrábida, em 2013 e Memórias do Sado, em 2014 (Figura 3).

Entretanto, em 2013 inicia-se o Mercado Romano (Santos, et al., 2017: 159; Magalhães, 2019), uma recriação histórica de época romana, com muita animação histórica, quadros vivos, espectáculos, música, actividades temáticas, espaços lúdicos e actividades próprias para crianças, área de mercado com bancas de artesanato e produtos regionais alusivos à época romana e espaço de restauração (tabernae). O Mercado Romano teve a sua primeira edição a 30 de Março de 2013 e recebeu cerca de 1.600 visitantes. Em 2014 e 2015, o evento foi alargado a dois e três dias, em Abril e Maio, respectivamente, e ultrapassou os 4 mil visitantes em cada uma destas edições. Na quarta edição, em 2016, com a duração de dois dias, em Abril, acolheu cerca de 3.280 visitantes. Na sua última edição, em 2017, num fim-de-semana de Abril, recebeu 1.641 visitantes. Estes números refletem a adesão do público a este tipo de evento e a oscilação do número de visitantes reflete condicionantes locais, como uma greve da empresa de ferries de acesso a Tróia em 2015, que limitou o transporte de Setúbal, e condições atmosféricas, como a chuva ou o excesso de calor, uma vez que é inteiramente desenvolvido no exterior. Em cada um dos anos foi escolhido um tema: em 2013 e 2014, a "Páscoa Romana"; em 2015, os "Ludi Florales"; em 2016, o "Festival do Garum" e, em 2017, "Em nome do deus Mitra". Todas as edições deste evento contaram com o apoio da Câmara Municipal de Grândola, da Câmara Municipal de Setúbal, da Infratróia, do MAEDS, do Museu Arqueológico de São Miguel 
de Odrinhas, do Museu de Lisboa - Teatro Romano e, pontualmente, de outras entidades (Figura 4).

A par deste grande evento anual, outros mais pequenos foram sendo criados e evoluindo. A partir de 2013, um Protocolo com a Associação Mutualista Montepio deu origem aos Sunsets Musicais, com direcção artística de Luís Filipe Canelas Martins, em época alta (nas quartas-feiras da segunda quinzena de Julho e de Agosto). Estes pequenos eventos de música ao vivo permitiram que os visitantes usufruíssem gratuitamente de um pequeno concerto e da visita ao sítio. Ao todo, participaram neste evento, no período de 2013 a 2017, 1032 pessoas. Em 2018 e 2019, os concertos continuaram com o patrocínio da Associação Mutualista Montepio, mas à música associaram-se as provas vínicas, com o apoio da Rota dos Vinhos da Península de Setúbal, promovendo as adegas regionais da península de Setúbal e da costa alentejana, e a entrada passou a ser paga. Esta reformulação trouxe ao sítio arqueológico um novo tipo de público e, no conjunto dos sete Sunsets de cada ano, participaram um total de 427 pessoas.

Em 2015, criou-se um novo pequeno evento de Verão no sítio arqueológico, a Noite de Estrelas. Esta consiste numa parceria com a Sky4All, na qual um astrónomo amador, com dois telescópios, acompanha os visitantes na descoberta dos astros e das estrelas do céu noturno, enquanto as arqueólogas contam os mitos relacionados com os planetas e as constelações que se podem observar. O evento tem lugar dentro de uma oficina de salga e tem a lotação de 50 pessoas. Em Agosto de 2015 concretizou-se a primeira sessão; em 2016 tiveram lugar três, em Julho e Agosto; em 2017 realizaram-se quatro em Agosto; em 2018, foram seis sessões em Julho e Agosto, e em 2019, foram quatro nos mesmos meses. Pode-se considerar um dos programas com maior sucesso, uma vez que as sessões esgotam a capacidade sistematicamente, e muitos participantes repetem de ano para ano, e por vezes regressam para descobrir o sítio à luz do dia, verificando-se uma grande aproximação do público ao monumento propriamente dito, talvez pelo caracter intimista da própria atividade em si (Figura 5).

Em 2017, escolheu-se como tema condutor da programação mensal das Ruínas Romanas de Troia, os deuses romanos. Assim, cada mês foi adoptado um deus e desenvolveram-se actividades ajustadas a cada um. Por exemplo, no mês de Baco houve uma prova de vinhos e no mês de Diana, uma exibição de voo de aves de rapina, no mês de Julho, dedicado a Apolo, organizou-se um Arraial com várias valências, além da incontornável sardinhada. Os alunos da CEAACP-Troia Summer School (adiante apresentada) mostraram os resultados das escavações terminadas na véspera e o Museu do Trabalho Michel Giacommeti, de Setúbal, organizou uma actuação teatral de um grupo de antigas trabalhadoras das fábricas de conservas, e todos os participantes foram convidados a visitar o sítio arqueológico.

Em 2018, promoveu-se uma "Bienal de Teatro", inaugurada com a peça ao ar livre "Viriato", do grupo Fatias de Cá, encenada pela primeira vez em Tróia. No ano seguinte, a Décadas de Sonho produziu o "O Cavalo de Troia", um espetáculo que combina teatro, acrobacia, dança, luz e som, especificamente criado para a margem da lagoa da Caldeira junto ao sítio arqueológico.

Também nos anos de 2018 e 2019 se desenvolveu um novo programa, a Noite Assombrada, que contou com a participação de muitos voluntários, nomeadamente do grupo de teatro ENSAIARTE, da Faculdade de Letras de Lisboa e da Escola Secundária Inácio da Cruz, Grândola, além de outros que participaram individualmente. Este evento decorreu pela primeira vez a uma sexta-feira 13, em Julho de 2018, guiando diferentes grupos pelas histórias mais sombrias que as escavações têm permitido conhecer. Este programa foi repetido a 19 de Julho de 2019, e a sua preparação contou com um workshop de teatro imersivo coordenado pelo encenador Prof. Newton de Sousa no Museu de Arqueologia e Etnografia do Distrito de Setúbal (MAEDS), que serviu para formação dos voluntários que fariam parte da encenação (Figura 6).

\section{ALGUNS PEDAIS: A COMUNIDADE ESCOLAR}

O serviço educativo não é dedicado apenas à comunidade escolar, mas, na perspectiva desta equipa, ela desempenha um papel fundamental na captação de futuros públicos e na educação não formal dos jovens. Papel esse que foi logo considerado ao ter-se instalado um projecto de valorização acessível (Pinto, Magalhães e Brum, 2014), com painéis explicativos à altura de visitantes mais pequenos e com ilustrações que reconstituem o que veem.

De início, foi feito um "Mini-Guia" com algumas actividades, que acompanhava e auxiliava a visita 
ao sítio. Os primeiros programas, iniciados com o ATL do Carvalhal, envolveram mascarar as crianças de Romanos e proporcionar-lhe uma actividade que se designou por "Romaninhos em Troia", no qual as crianças seguiam diversas pistas ao longo das ruínas. Esta realizou-se ainda antes da instalação dos percursos, pelo que o contacto com o monumento era em alguns casos mais próximo, como no caso das termas, onde as crianças podiam então entrar. Houve uma forte aposta na promoção das Ruínas Romanas de Tróia junto da comunidade escolar, como ponto estratégico do desenvolvimento do projecto de valorização. Identificaram-se, nas metas pedagógicas do Ministério da Educação, os anos escolares cujos conteúdos abarcavam a cronologia romana ( $5^{\circ}, 7^{\circ}$ e $10^{\circ}$ anos de escolaridade) e estes foram assinalados como público-alvo.

Foram criadas várias propostas especificamente para escolas: Actividades pedagógicas; Passeio pedestre; A salga de peixe e o arroz: indústrias do passado e do presente; Arqueologia e Ambiente; Visita e piquenique e Arqueologia e Golf, com a possibilidade de as escolas usufruírem de um preço especial na travessia do Sado pela Atlantic Ferries. A grande maioria das escolas opta simplesmente pelas actividades pedagógicas com o preço e o período de tempo mais reduzido na oferta existente. Os programas envolvendo o piquenique e o golf não tiveram procura e deixaram de fazer parte dos conteúdos promocionais produzidos em 2017.

A partir de 2013, e baseado no romance Um gladiador só morre uma vez de Steven Saylor, construiu-se o jogo de pista "O garum roubado", no qual os alunos são divididos em povos bárbaros (Gauleses, Egípcios, Bretões e Lusitanos, seguindo as imagens da banda desenhada Astérix e Obélix), após uma curta visita guiada. Os alunos são então deixados à sua própria exploração do sítio e testando o conhecimento recentemente adquirido, encontram as letras (P-O-Ç-O) espalhadas nas pistas deixadas em diferentes núcleos do percurso visitável. O jogo narra a história de uma garrafa de garum roubada, que afinal está esquecida no poço, e onde no final as crianças podem degustar o dito garum, substituído pelo molho de peixe produzido na Tailândia, nuoc mam. Segue-se nesta actividade o princípio de que "uma vez criados laços de alguma familiaridade com o ambiente, os alunos tendem a desenvolver um crescente grau de concentração" (Silva, 2007: 61) (Figura 7).
O conhecimento empírico obtido com esta actividade revelou que não era desafiante para o público do $7^{\circ}$ ano de escolaridade, pelo que foi necessário desenvolver uma acção específica para esta faixa etária. Essa nova actividade consiste na recriação de contextos arqueológicos, que são repartidos entre diferentes grupos de alunos que devem registar, desenhar e interpretar as peças do seu contexto conforme o procedimento arqueológico, apresentando-o no final aos restantes grupos, e realçando-se o trabalho de equipa que se desenvolve em arqueologia.

De realçar ainda dois programas específicos que procuraram fazer chegar o sítio arqueológico mais directamente à escola: "Adota uma ruina" e "Garum nostrum". O programa "Adota uma ruína" (Santos, et al., 2017: 158) decorreu nos anos letivos de 2015/2016 e 2016/2017. Os objetivos deste projeto foram "estimular o interesse das crianças e jovens pelo património cultural local e incentivá-los a valorizá-lo".

O "Garum nostrum" teve o objectivo de ajudar as pessoas (das gerações mais jovens, mas naturalmente através de um público mais amplo) a formar uma visão mais complexa do cenário europeu, facilmente demonstrada pelos vestígios romanos que foram determinantes neste território, esperando dar uma ideia melhor sobre o que cada um pode contribuir no panorama europeu.

Assim, o público escolar nas Ruínas Romanas de Tróia cresceu nos últimos anos (Figura 8), sendo particularmente notório o ano lectivo 2017/2018, possivelmente reflexo do investimento continuado nos programas escolares em Tróia (Figura 8).

Por outro lado, as escavações fizeram sempre parte do trabalho desenvolvido nas Ruínas Romanas de Troia, e desde 2007 que se envolveram estudantes de várias universidades do país. Em 2014, iniciou-se a CEAACP-Troia Summer School, uma parceria com o Centro de Estudos de Arqueologia, Artes e Ciências do Património da Universidade de Coimbra e com o apoio da Universidade do Arizona. Aqui procurou criar-se uma escola de verão, onde os alunos participavam na escavação do sítio arqueológico, sendo o programa complementado com aulas proporcionadas pela equipa residente e por oradores convidados. Este programa de Verão começou por ter como público-alvo estudantes universitários internacionais, mas desde 2018 foi direcionado, com apoio da AFAR (American Foreign Academic Research), ao segmento de pré-universitários do ensino secundário. 


\section{AS CORREIAS DA CARROÇA: PARCERIAS E INTEGRAÇÃO EM PROGRAMAS EXISTENTES}

Para além da programação acima apresentada e originalmente criada para este sítio arqueológico, também foi acolhida a participação em feiras, festas e outros encontros que são vistos como motores conjuntos para a promoção do património cultural. A título de exemplo, as Ruínas Romanas de Tróia participaram, desde 2012, na Festa da Arqueologia, promovida pela Associação dos Arqueólogos Portugueses e Museu Arqueológico do Carmo, na recriação histórica iniciada em S. Miguel de Odrinhas em 2018 e em iniciativas promovidas pelo Museu de Lisboa - Teatro Romano.

As Ruínas Romanas de Troia desenvolveram programação nas edições do Dia Internacional dos Monumentos e Sítios, dia instituído a 18 de Abril de 1982 pelo Conselho Internacional dos Monumentos e Sítios (ICOMOS). Integraram as celebrações, geralmente, com um Dia Aberto e com acções criadas de acordo com o tema do ano. No primeiro ano, em 2011, pouco tempo depois da abertura ao público, foram acolhidos, com surpresa, 155 visitantes (Figura 9).

Para além do acesso gratuito, em 2012 decorreu uma visita guiada com o tema "A singularidade do sítio arqueológico de Tróia”, e em 2013 e com o tema "Memória e Identidade das Ruínas Romanas de Tróia". Em 2014, a comemoração foi integrada no evento Mercado Romano. Em 2015, a programação dedicou-se à Basílica Paleocristã, com apresentações sobre as suas pinturas e os trabalhos de conservação e restauro no Golf de Tróia, e visitas guiadas gratuitas a este núcleo. Em 2016, foram disponibilizados jogos de tabuleiro para que os visitantes pudessem usufruir de um desafio diferente, e no dia 18, sábado, foi realizado um ensaio para o desfile do Mercado Romano. Em 2017, no âmbito do projeto europeu STORM e do projeto pedagógico "Adota uma ruína”, alunos de duas escolas do concelho vizinho de Setúbal desenvolveram actividades que alertavam para as ameaças ao património cultural, nomeadamente a erosão fluvial e o vandalismo. Nos anos de 2018 e em 2019, decorreram dias abertos, sem programação adicional.

Por seu turno, as Jornadas Europeias do Património, uma iniciativa conjunta da Comissão Europeia e do Conselho da Europa desde 1999, foram integradas na programação a partir de 2013 , realizando-se anualmente um passeio pedestre na orla do estuário do Sado, sensibilizando para o património arqueológico ameaçado pela erosão costeira e que ainda não foi objeto de valorização.

Desenvolveram-se ainda parcerias mais pontuais e locais, fruto de algumas oportunidades que serão já resultado de uma maior proximidade com a comunidade local. $\mathrm{O}$ ano de 2017 teve duas iniciativas nas freguesias mais próximas: o desfile de Carnaval com temática romana (Santos, et al., 2017: 162), em Melides, e o arraial do Carvalhal, com uma marcha e música personalizadas. No ano seguinte, no âmbito do desafio do Ano Europeu do Património Cultural, a Sociedade Musical Filarmónica Operária de Grândola - Música Velha tocou o Hino da Alegria no sítio arqueológico, tendo o concerto sido divulgado nas redes sociais a 9 de Maio, celebrando o Dia da Europa (Figura 10).

O envolvimento de outros agentes culturais não é efectuado apenas ao nível da divulgação e programação, mas foi procurado na própria investigação. Em parceria com a Câmara Municipal de Setúbal, e mais concretamente com o Museu do Trabalho Michel Giacometti, desenvolveu-se a partir de 2016, o Centro de Memórias das Ruínas Romanas de Tróia. O sítio arqueológico vem sendo escavado desde o século XVIII, com intensas campanhas de escavação nos anos 50 e 6o. Com o intuito de não perder as memórias daqueles que vêm contactando com o sítio arqueológico e que contribuíram para o desenvolvimento do seu conhecimento, este projecto propõe-se recolher os testemunhos da relação com o sítio daqueles que estiveram de alguma forma envolvidos na investigação deste sítio arqueológico.

\section{OS EIXOS DA CARROÇA: DISCUSSÃO}

Can we say with as much confidence that heritage interpretation has played an important role in enhancing peoples awareness, understanding and appreciation of time and place? (Uzzell, 1998: 1)

Tal como Tilden (1977), entendemos a interpretação/mediação como o início de um processo que leva à protecção do património. Como referido noutra parte: "No nosso trabalho percebemos como as pessoas só se ligam ao sítio depois de compreenderem a sua história. Então, temos de contar a história milhares de vezes e de muitas formas diferentes." (Santos, 2018). 
Os programas que ora se apresentaram, têm por base a investigação da equipa residente de arqueólogas, que procuram no mundo romano a inspiração para as recriações históricas, teatros ou o contar de mitos. Como a equipa de investigação é simultaneamente a equipa do serviço educativo, anula-se a barreira investigação/mediação. Quem planeou, investigou e "produziu a exposição permanente" é simultaneamente quem faz a difusão e divulgação da mesma, recebendo directamente a reacção do público que a visita.

As actividades aqui apresentadas foram originalmente criadas para desenvolver a atractividade do destino turístico com uma nova oferta cultural, diferente do turismo de praia e sol, reconhecendo-se neste projecto que o turismo poderá favorecer o respeito pelos valores patrimoniais e a preservação da herança cultural (Pinto et al., 2019: 19). Ao mesmo tempo, visava provar o apelo do sítio e ampliar os públicos, incentivando a criação de novos empregos e oportunidades de negócios na região e promovendo a sustentabilidade do património cultural.

Através de muitos destes programas, mas talvez sobretudo das recriações do Mercado Romano, Noites Assombradas e programas educativos, foi possível um maior envolvimento e participação das comunidades, complementando a capacidade da equipa que coordenava os eventos. O envolvimento de instituições de teatro amador, escolas e universidades nas actividades, a promoção de um concurso entre famílias locais ou o desenvolvimento do mercado com artesãos desenvolveram novas perspectivas para o património, usando a história para aproximar as pessoas e corresponder às suas expectativas.

Com o desenvolver de um circuito de visita, o palco estava montado para uma nova fase na Tróia romana. A visão para este sítio tornou-se mais clara: "constituir-se como pólo cultural de qualidade, tornando-se local de referência do turismo cultural internacional, atraindo simultaneamente públicos locais e estrangeiros e actuando como factor diferenciador do Troiaresort" (Brum, 2014).

A existência de recursos humanos com elevada formação e a clara definição de uma missão/visão permitiram mediar o envolvimento de todos os agentes ligados a este sítio, incrementando o significado cultural do sítio e estimulando a sua funcionalidade, de forma a assegurar o compromisso de todas as partes na salvaguarda do bem (ICCROM, 2015).

Dez anos depois, o serviço educativo deste equi- pamento cultural não só alargou a transmissão de conhecimento em formato de visita guiada, mas também procurou reinventar-se, compreendendo a importância das comunidades que a rodeiam e que estavam arredadas do sítio, com "a liberdade e o poder de explorar a sua imaginação e a sua ligação pessoal com o sítio" (Santos, 2018). Foi caminho da equipa que assina este artigo procurar transformar as Ruínas Romanas de Troia num espaço convidativo, entendido como espaço de sociabilidade e de contacto directo com o património, em que se ensina que peixe puxa carroça!

\section{BIBLIOGRAFIA}

BRUM, P. (2014) - Contributos para a programação museológica do acervo arqueológico romano de Tróia. Museu ou Centro de Interpretação?, Tese de Mestrado. Faculdade de Ciências Sociais e Humanas-Universidade Nova de Lisboa, Lisboa.

MAGALHÃES, A. P. (2019) - Roman market (Portugal), European heritage strategy for the $21^{\text {st }}$ century - the golden collection of good practices, pp. 77-79.

PINTO, I. V.; MAGALHÃES, A. P.; BRUM, P. (2014) - Ruínas Romanas de Tróia: a valorização de um património singular, Revista Musa 4, MAEDS, Setúbal, pp. 29-40.

PINTO, I. V.; MAGALHÃES, A. P.; BRUM, P. e SANTOS, F. (2019) - Entre o valor Patrimonial e o Interesse turístico: como usufruir do maior centro de preparados de peixe do Império romano, Arqueologia 3.o, Fundação da Casa de Bragança, pp. 14-24.

SANTOS, Filipa (2018) - What do you think and feel cultural heritage really means? Roman Ruins of Troia archaeologists team (Portugal). <http://patrimoni.peu-uji.es/es/ noticias/1423-what-do-you-think-and-feel-cultural-heritage-really-means-contribution-of-filipa-araujo-santosroman-ruins-of-troia-archeologists-team-portugal>. [Consulta realizada em 24/o2/2018].

SANTOS, F., BRUM, P., PINTO, I. V., MAGALHÃES, A. P. (2017) - O envolvimento da comunidade escolar com as Ruínas Romanas de Troia, XXIV Congresso Internacional de Animação Sociocultural, APDASC - Associação Portuguesa para o Desenvolvimento da Animação Sociocultural, pp. 155-164.

SAYLOR, S. (2009) - Um gladiador só morre uma vez. Bertrand Editora.

SILVA, S. G. (2007) - Enquadramento teórico para uma prática educativa nos museus. PRAÇA, J.H. (Ed.), Serviços Educativos na Cultura (57-66). Porto: SETEPÉS, pp. 57-65.

TILDEN, F (1977) - Interpreting our heritage, Chapell Hill Books. 
UZZELL, DL (1998) - Interpreting Our Heritage: A Theoretical Interpretation, UZZELL DL e BALLANTYNE, R. (eds.) Contemporary Issues in Heritage and Environmental Interpretation: Problems and Prospects, London: The Stationery Office. pp. 11-25.

VASCONCELOS, J. L. (1897) - Escavações reais em Tróia. O Archeólogo Português. Lisboa: Museu Etnológico Português, vol. III, págs. 2-31, p. 156-265.
ICCROM (2015) - People-Centred Approaches to the Conservation of Cultural Heritage: Living Heritage. Rome: ICCROM.

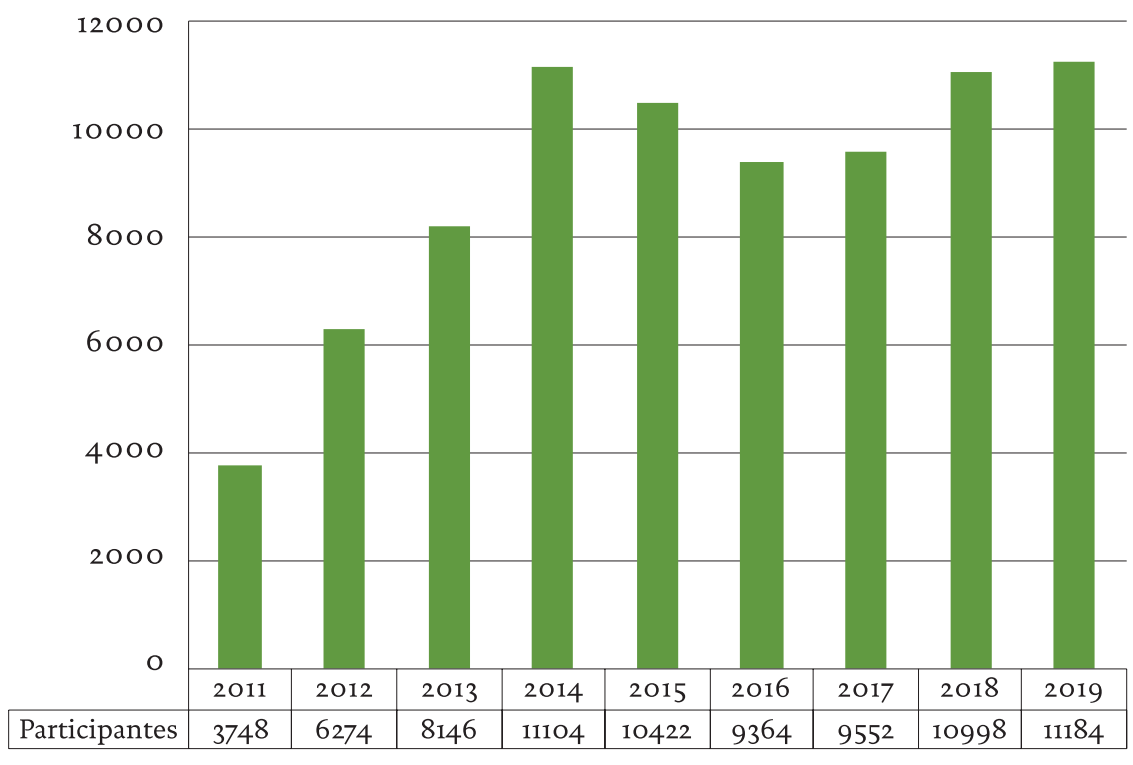

Figura 1 - № de visitantes de 2011 a 2019.

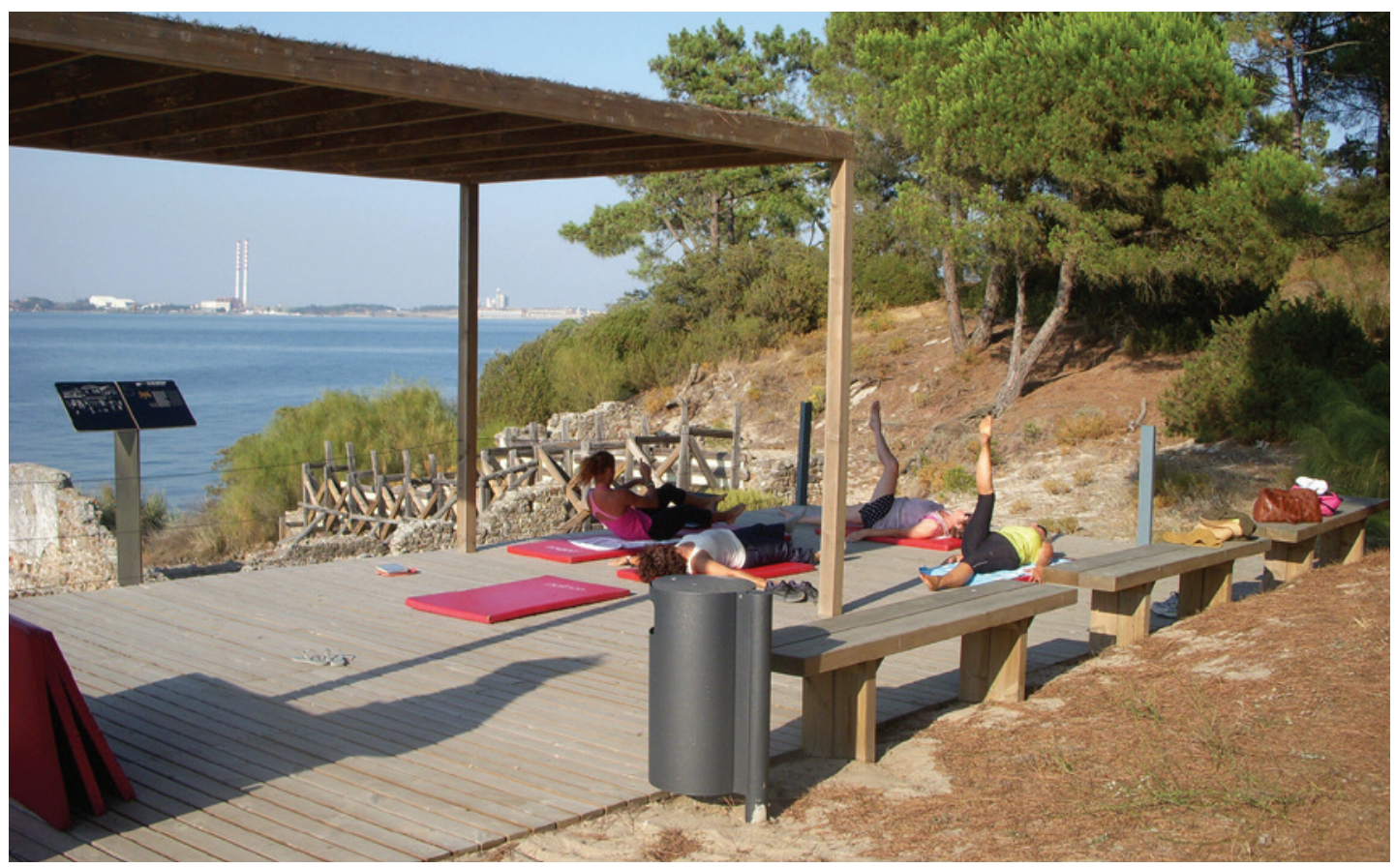

Figura 2 - Sessão de alongamentos com vista para o núcleo da Rua da Princesa. Foto de Inês Vaz Pinto. 


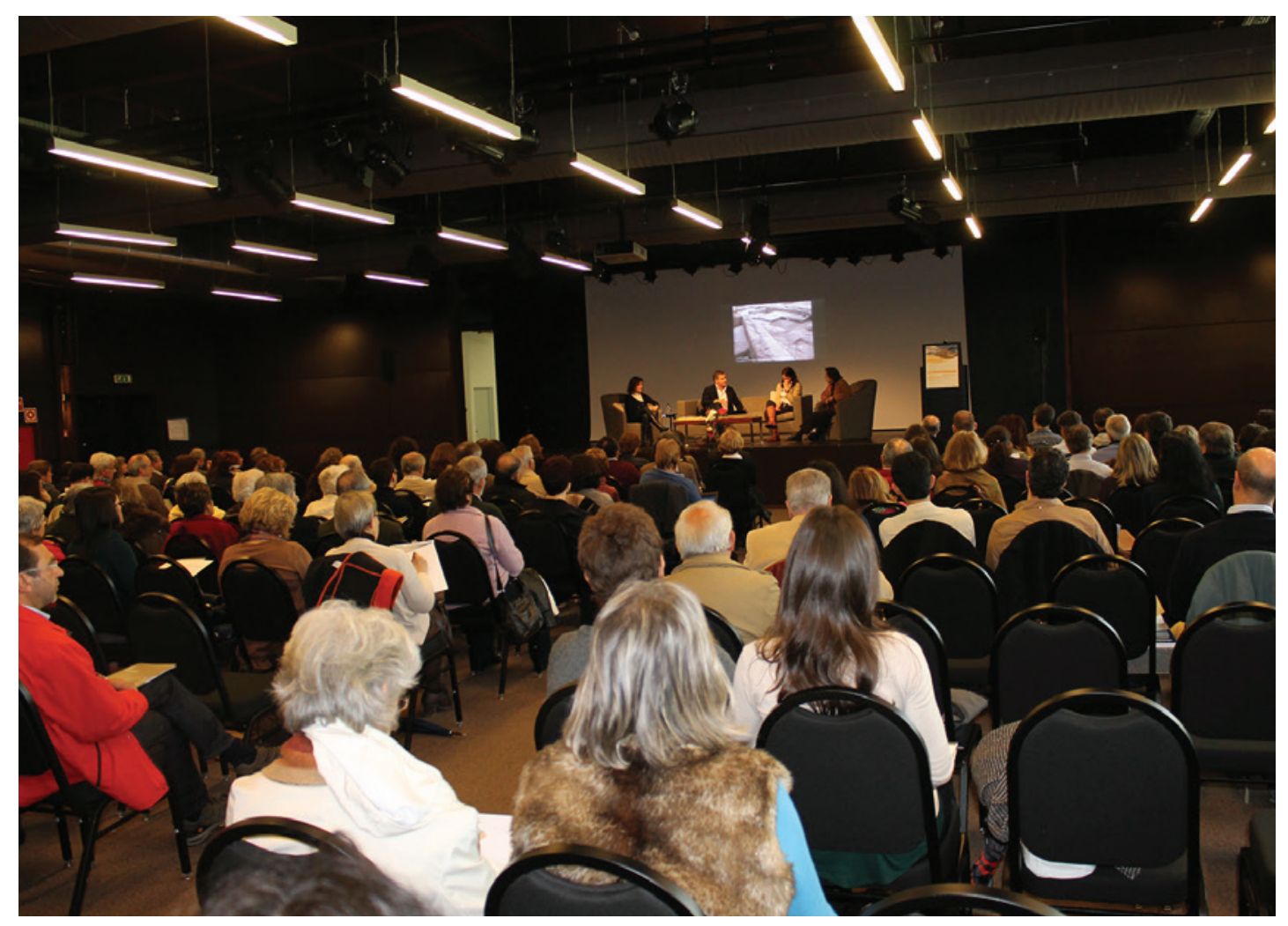

Figura 3 - Sessão das Memórias da Arrábida. Foto de Inês Vaz Pinto.

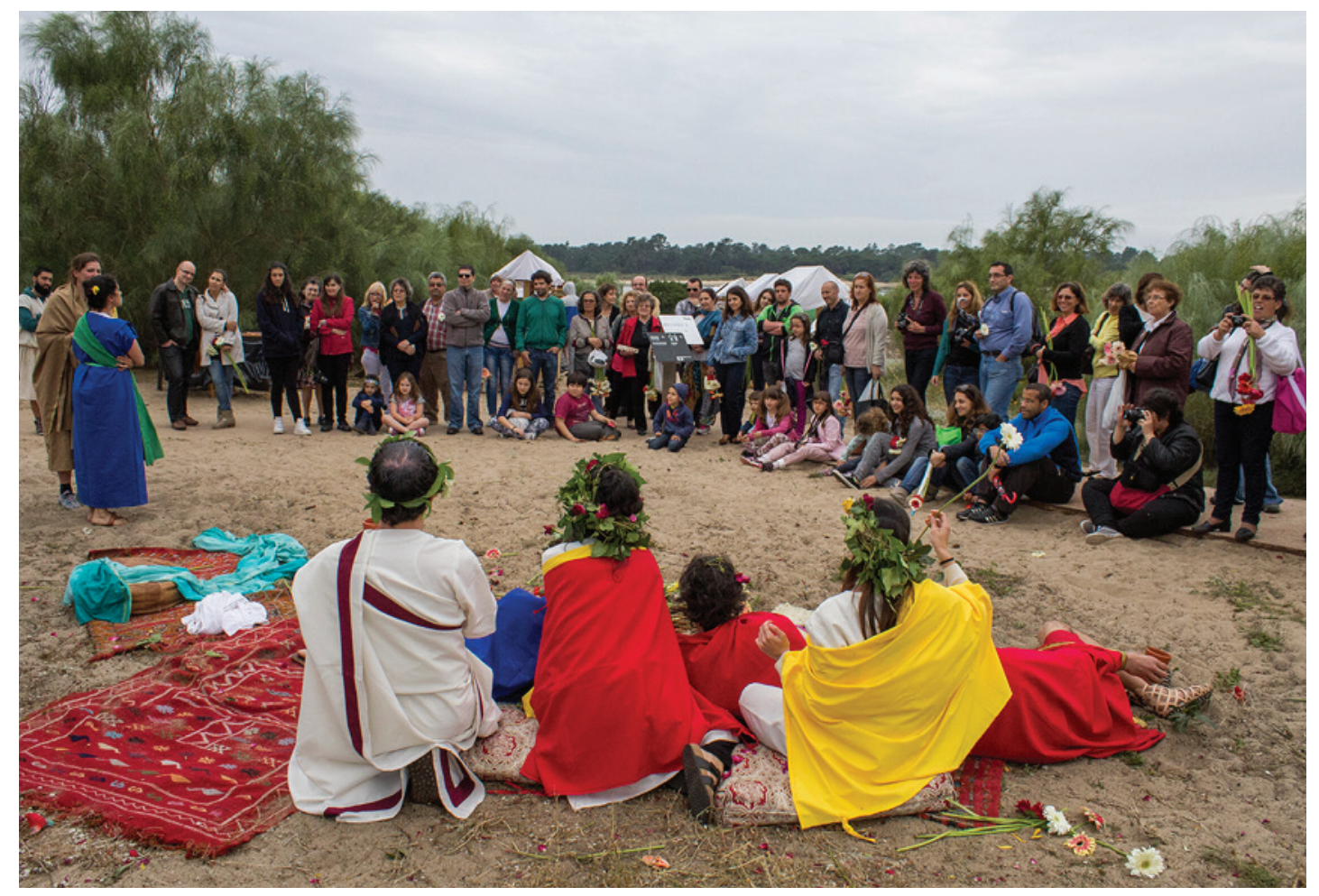

Figura 4 - Edição “Ludi Florales” do Mercado Romano. Foto de Inês Vaz Pinto. 


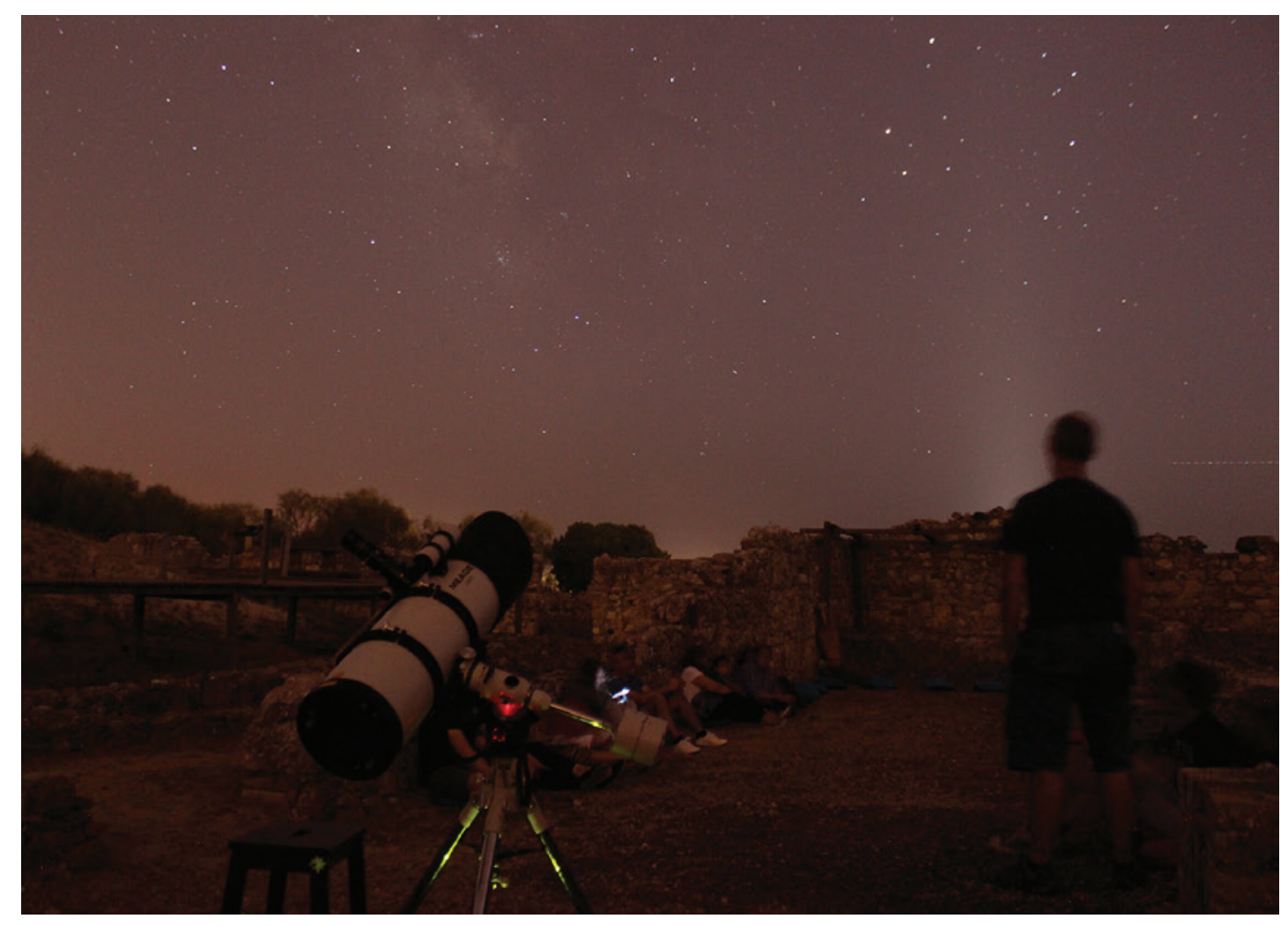

Figura 5- Noite de Estrelas a 26 de Agosto de 2016. Foto de Luís Gabriel.

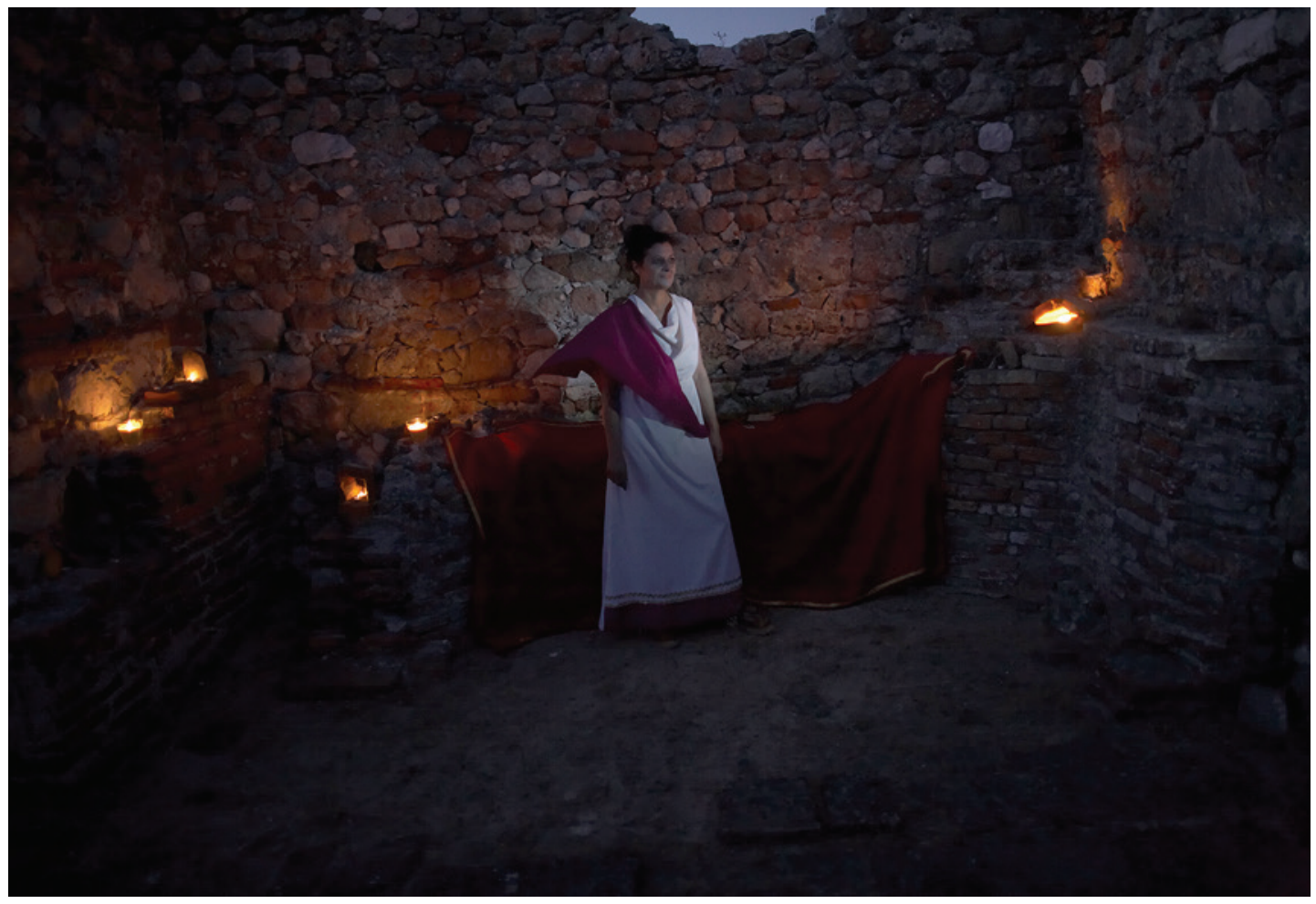

Figura 6 - Noite Assombrada em 2019. Foto de Inês Vaz Pinto. 


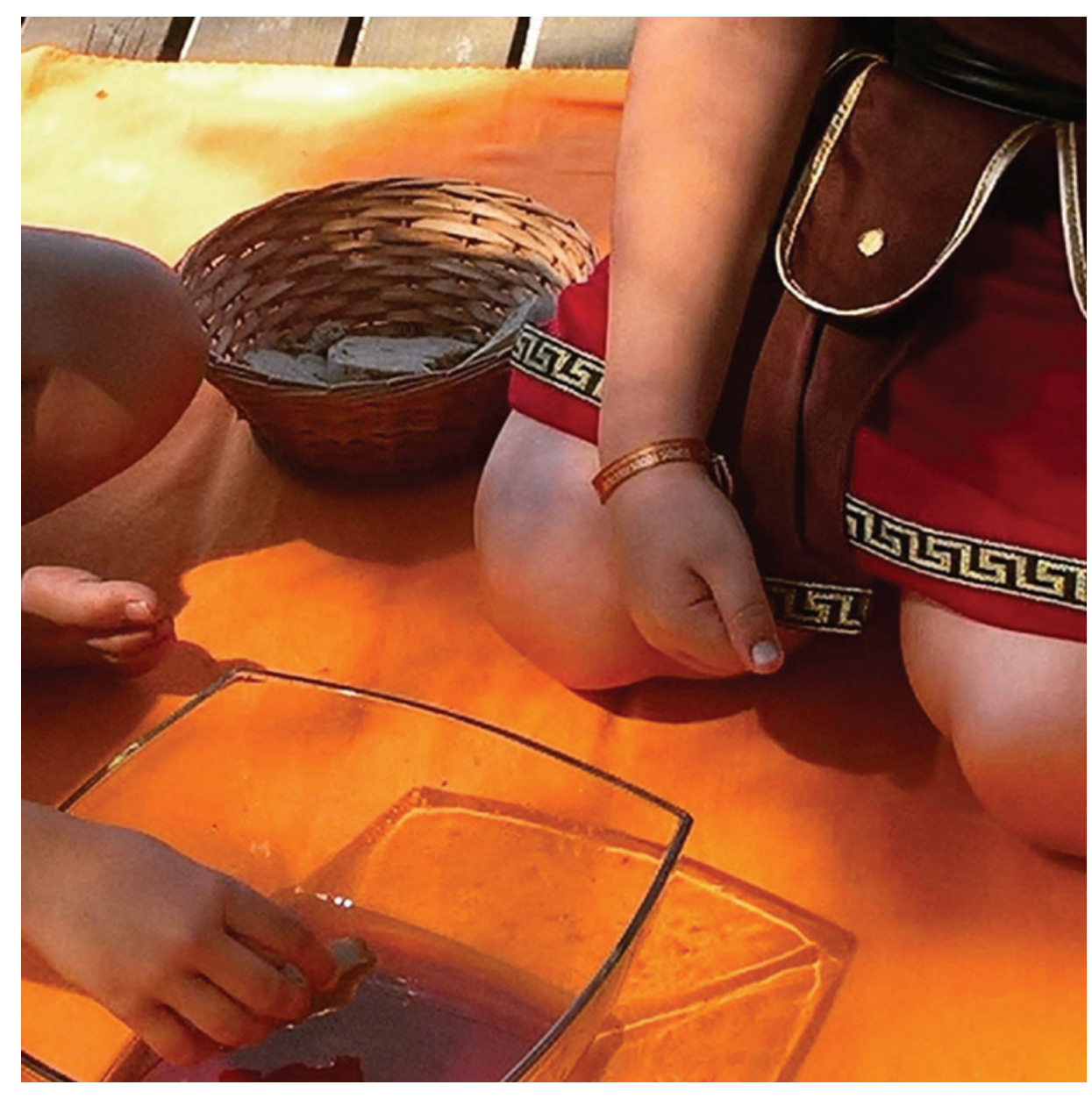

Figura 7 - Prova de garum no Dia Mundial da Criança em 2019. Foto de Patrícia Brum.

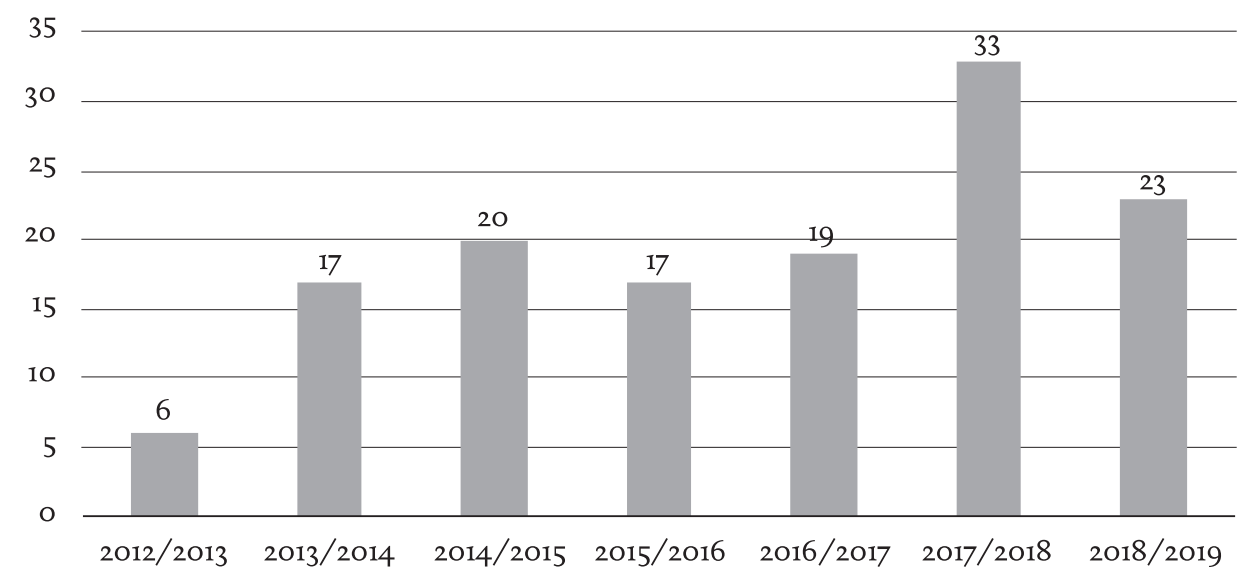

Figura 8 - Gráfico do público escolar por ano lectivo. 


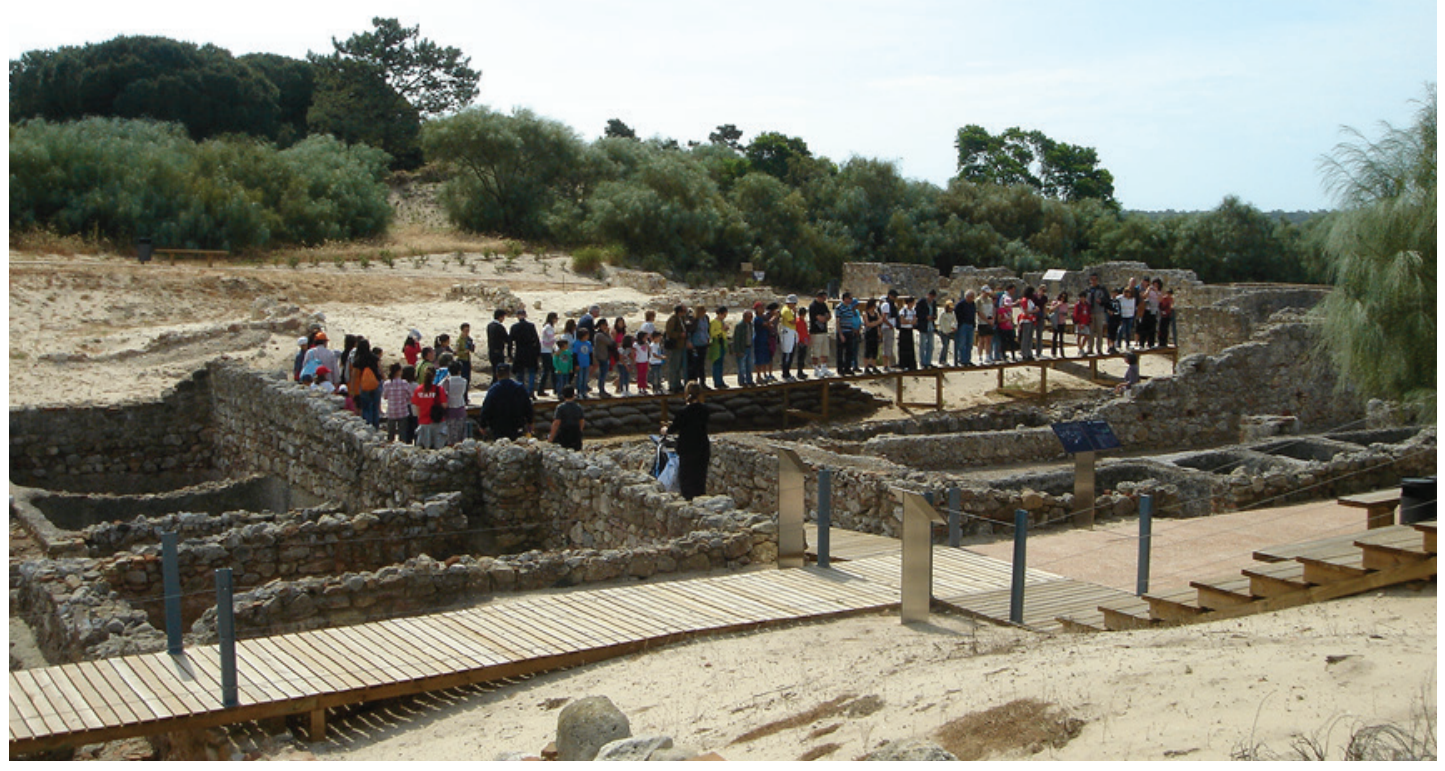

Figura 9 - Primeira edição do Dia Internacional dos Monumentos e Sítios nas Ruínas Romanas de Tróia. Foto de Patrícia Brum.

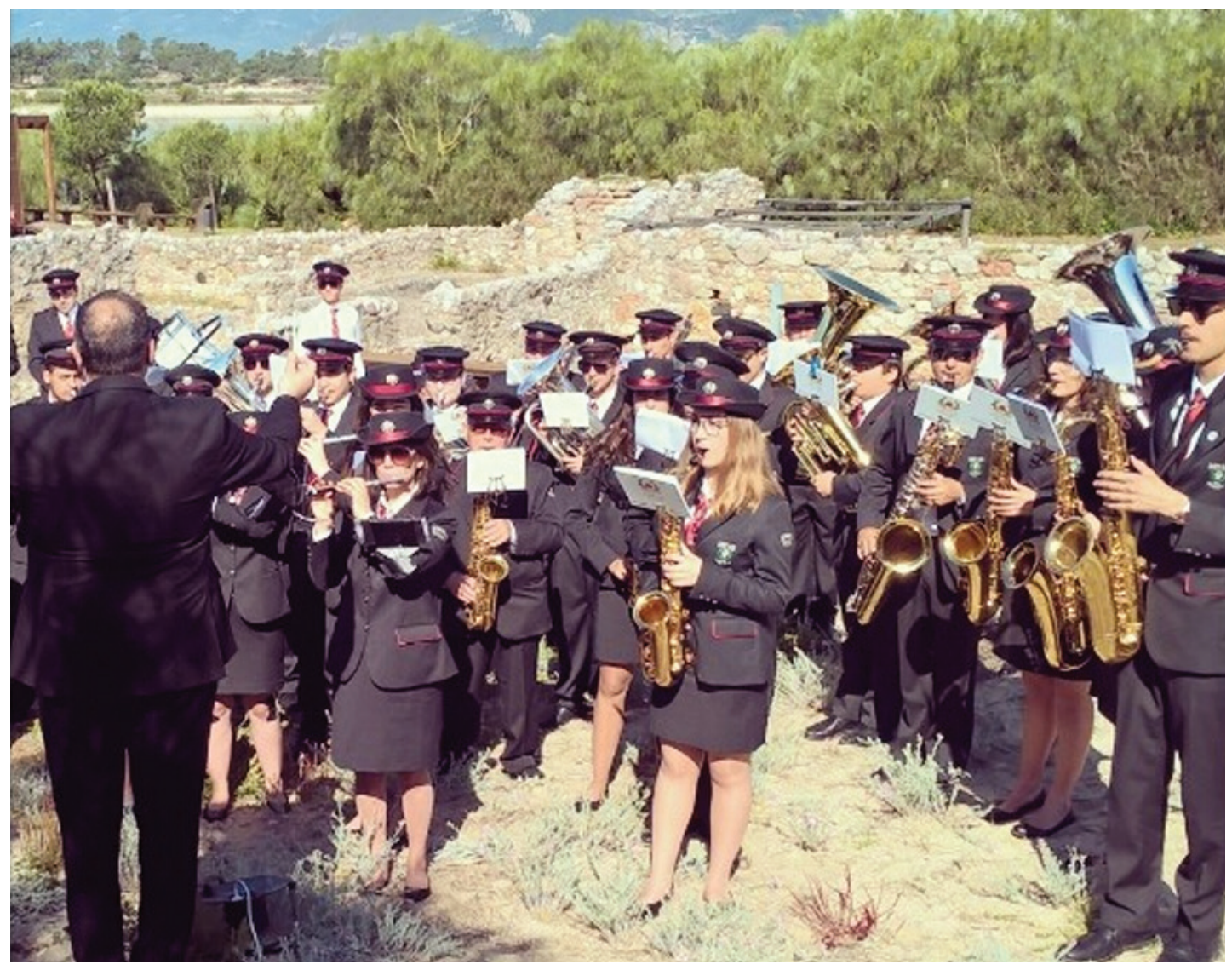

Figura 10 - Sociedade Musical Filarmónica Operária de Grândola - Música Velha nas Ruínas Romanas de Tróia. Foto de Patrícia Brum. 


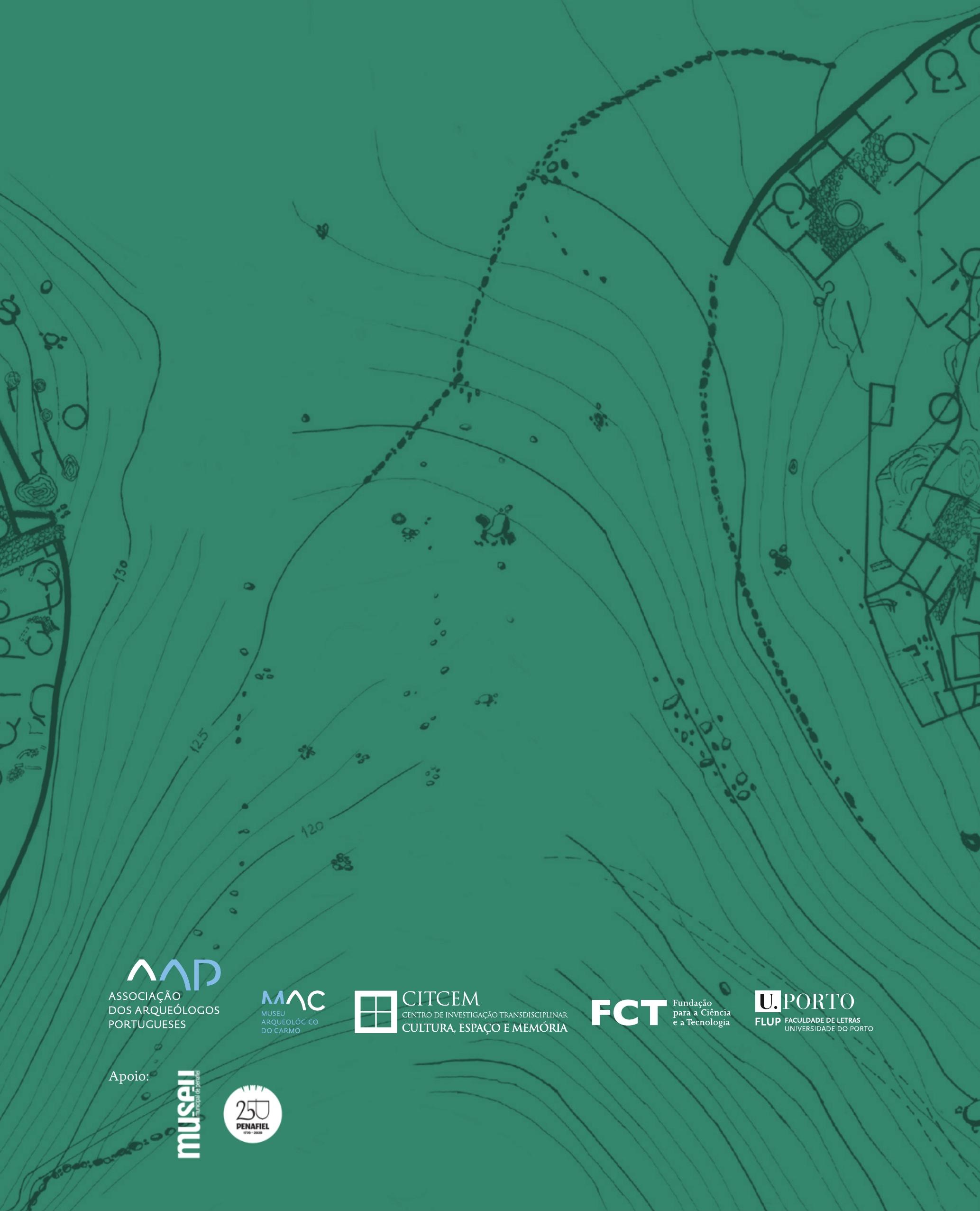

